\title{
KAJIAN PERBANDINGAN GAYA ARSITEKTUR DAN POLA RUANG MASJID AGUNG SURAKARTA DAN MASJID GEDHE KAUMAN YOGYAKARTA
}

\author{
Nur Rahmawati Syamsiyah \\ Prodi Arsitektur Fakultas Teknik \\ Universitas Muhammadiyah Surakarta \\ nur rahmawati@ums.ac.id
}

\section{Andiarta Muslim}

Prodi Arsitektur Fakultas Teknik

Universitas Muhammadiyah Surakarta andiartamuslim@gmail.com

\begin{abstract}
ABSTRAK
Masjid merupakan tempat dimana seorang muslim beribadah kepada Allah dengan khusyuk. Kehadiran masjid sangat penting bagi kehidupan muslim, sehingga tidak heran jika masjid menjadi salah satu objek penting yang sering berkaitan dengan dunia arsitektur dalam perancangannya. Masjidmasjid Mataram Kuno merupakan bangunan yang mempunyai nilai sejarah tinggi bagi umat Islam di Indonesia khususnya di Jawa. Keberadaan masjidmasjid tersebut bukan hanya sebagai tempat ibadah tetapi juga menjadi salah satu identitas umat Islam di Jawa yang diwujudkan dalam suatu bentuk arsitektural seperti ruang beserta ornamennya. Penelitian ini bertujuan untuk mengetahui gaya arsitektur dan pola tata ruang Masjid Agung atau Masjid Gedhe Surakarta dan Masjid Kauman Yogyakarta. Penelitian ini menggunakan metode kualitatif, melalui pengamatan fisik masjid, lalu melakukan analisis yang sifatnya diskriptif. Hasil penelitian menunjukkan adanya perbedaan dan persamaan kedua masjid tersebut dari segi gaya arsitektur dan pola tata ruangnya. Persamaaan yang diperoleh antara lain tipologi ruang dan bentuk arsitektur. Sedangkan perbedaan seperti gaya arsitektur Jawa yang memiliki keunikan masing-masing seperti adanya pengaruh gaya arsitektur Eropa dan Timur Tengah.

KATA KUNCI : gaya arsitektur; masjid; perbedaan; persamaan; ruang
\end{abstract}

\section{PENDAHULUAN}

Masjid adalah suatu bangunan peribadatan yang memiliki disain khusus, dan bersifat suci, memiliki batas di sekelilingnya yang memisahkan dengan area tidak suci, sebagai tempat untuk beribadah kepada Allah SWT, khususnya untuk mengerjakan shalat. Selain itu masjid juga menjadi tempat yang vital bagi kegiatan umat Islam. Kegiatan di masjid bukan hanya dari segi ibadah mahdah saja seperti shalat, membaca Al-Qur'an, dzikir dan sebagainya, namun juga kegiatan- vital lainnya seperti dakwah, kegiatan sosial kemasyarakatan, juga kegiatan transfer ilmu agama. Peran masjid yang sangat penting tersebut, maka tidak diragukan lagi bahwa sangat penting bangunan masjid dan ruang-ruang di dalamnya, dan ruang luar/lingkungan masjid.

Di era globalisasi sekarang ini, adalah suatu yang penting untuk meneliti dan melihat kembali keadaan-keadaan masjid sekarang ini, khususnya masjid-masjid kuno di Jawa, yang berusia lebih dari 2 abad. Ketertarikan meneliti masjid kuno sebagai basic knowledge, diawali dengan keprihatinan melihat kondisi kebanyakan masjid khususnya di tanah Jawa, kurang mencirikan identitas tradisional Jawa. Oleh karena itu diperlukan kajian untuk menggali kembali khazanah arsitektural masjid-masjid yang masih mempunyai identitas Jawa. Objek yang akan dikaji adalah Masjid Agung Surakarta dan Masjid Gedhe Yogyakarta, sebagai masjid kerajaan Islam Mataram, yang masih memiliki karakteristik identitas dari masyarakat Jawa. Pemilihan dua masjid tersebut didasari kesamaan pada ciri fisik maupun non fisik bangunan. Kesamaan yang paling pokok yaitu gaya arsitektur tradisional Jawa yang masih kental, sebagai masjid keraton atau masjid kerajaan Mataram Islam.

Selain unsur kesamaan, penelitian ini berupaya menggali unsur yang membedakan antara kedua masjid. Perbedaan dari keduanya lebih ditekankan pada gaya arsitektur dan pola tata ruang nya dan halhal lain yang dapat menjadi pembanding antara kedua masjid tersebut. Kajian masjid agung yang berbeda kota ini, dapat memperkaya khasanah literatur arsitektur tradisional Jawa, terutama dalam hal membangun masjid yang berkarakter tradisional Jawa.

Temuan adanya unsur kesamaan dan perbedaan akan menjadi semacam design guideline bagi perencanaan masjid berkarakter tradisional Jawa di kemudian hari. Penelitian ini diharapkan akan membawa manfaat bagi praktisi, professional arsitek, dan akademisi, dalam menentukan tata letak masjid terhadap lingkungan serta simbolisasi masjid yang diempiriskan melalui gaya arsitekturnya. Lingkungan kehidupan masyarakat sekitar masjid menjadi pertimbangan penting demi kemakmuran masjid. 


\section{TINJAUAN PUSTAKA}

\section{Gaya Arsitektural}

Arsitektur adalah ilmu yang mempelajari bentuk dan ruang. Ruang disini mencakup pengertian yang kompleks, karena arsitektur pada prinsipnya terdiri dari unsur ruang, keindahan, fungsional dan kekuatan (Vitruvius, 1914). Ruang dalam arsitektur adalah untuk pemenuhan kebutuhan manusia atau kelompok manusia dalam melaksanakan aktivitas tertentu. Arsitektur dipandang sebagai ungkapan fisik dan peninggalan budaya dalam suatu masyarakat tertentu, yang memiliki batasan waktu dan tempat.

Arsitektur erat kaitannya dengan budaya dan keadaan lingkungan dari suatu geografis tertentu yang akhirnya dapat menunjukan suatu ragam yang mencirikan suatu daerah tersebut. Ragam ornamen bangunan yang sering digunakan dari berbagai daerah di Indonesia adalah flora, selain fauna dan alam juga ornamen geometris atau ornamen hias religi. Sementara itu gaya arsitektur merupakan ragam, baik itu dalam hal cara, rupa, bentuk dan lainnya yang khusus mengenai tulisan dan bangunan.

\section{Tata Elemen Arsitektural Jawa}

Pada bangunan arsitektur tradisional Jawa memiliki beberapa macam ornamen hias pada bangunannya, antara lain ornamen hias flora , fauna, alam, dan ornamen hias religi. Pada ornamen masjid lebih banyak menggunakan ragam jenis flora, alam dan religi ,hal tersebut tidak lepas dari pengaruh praIslam (jaman peralihan dari Hindu ke Islam. Flora yang digunakan sebagai ornamen hias pada bangunan Jawa memiliki makna suci, dan memiliki lebih banyak variasinya. Ragam hias ini juga merupakan simbol keindahan dan kebaikan dan biasanya menggunakan warna-warna seperti merah, hijau dan kuning atau emas (Cahyandari, 2012)

Berikut merupakan macam-macam ornamen hias di bangunan tradisional Jawa dengan kebiasaan perletakan dan artinya:

Tabel 1. Ragam Hias Flora: Arti dan Penempatan

\begin{tabular}{|c|c|c|c|}
\hline Nama & Wujud & Letak: & Arti/maksud \\
\hline Gunungan & $\begin{array}{l}\text { Bentuk gurung } \\
\text { secara sederhana } \\
\text { atan bentuk } \\
\text { pohon. }\end{array}$ & $\begin{array}{l}\text { Bubungan ruah di } \\
\text { tengah. }\end{array}$ & $\begin{array}{l}\text { Lambang alam } \\
\text { semesta dengan } \\
\text { puncal } \\
\text { keagungan. Kayon } \\
\text { atan pohon untuk } \\
\text { berlindung. }\end{array}$ \\
\hline $\begin{array}{l}\text { Mahkuta } \\
\text { Syctiat } \\
2.92\end{array}$ & Mahkota. & $\begin{array}{l}\text { Bubungan atap di } \\
\text { tengah atsu bagian } \\
\text { tepi kanan dan } \\
\text { kiri. }\end{array}$ & $\begin{array}{l}\text { Raja wakil dari } \\
\text { Tuhan } \\
\text { memberkahi seisi } \\
\text { rumah agar } \\
\text { selamat. }\end{array}$ \\
\hline 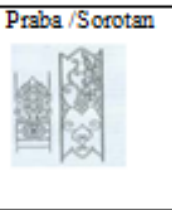 & $\begin{array}{l}\text { Ukiran berbentuk } \\
\text { melenkung } \\
\text { meninggi dengan } \\
\text { berujung di } \\
\text { tengah. Mirip } \\
\text { daun-dauna atan } \\
\text { kor merak }\end{array}$ & $\begin{array}{l}\text { Di tiang-tiang } \\
\text { (aska) sebelah atas } \\
\text { dan bawah pada } \\
\text { keempat sisi tiang. }\end{array}$ & $\begin{array}{l}\text { Sinar atsu } \\
\text { memberikan } \\
\text { cahaya pada tiang- } \\
\text { tiang sehingga } \\
\text { menambah } \\
\text { keindahan }\end{array}$ \\
\hline$\frac{\text { Panah }}{8+2}$ & $\begin{array}{l}\text { Anak panah yang } \\
\text { menuju ke satu } \\
\text { titik dalam bidang } \\
\text { segiempat }\end{array}$ & $\begin{array}{l}\text { Tebeng pintu } \\
\text { (sebelah atas } \\
\text { pintu), sembarang } \\
\text { pintu }\end{array}$ & $\begin{array}{l}\text { Sebagai ventilasi, } \\
\text { delapan senjata } \\
\text { dari } 8 \text { arah mata } \\
\text { angin dapat } \\
\text { sebagai penolak } \\
\text { bala. }\end{array}$ \\
\hline $\begin{array}{l}\text { Kepetan } \\
\\
\end{array}$ & $\begin{array}{l}\text { Bentuk } 1 / 4 \\
\text { linglvaran, sisi } \\
\text { lengkung tombak }\end{array}$ & $\begin{array}{l}\text { Di patang aring } \\
\text { senthong, daun } \\
\text { pintu, dinding } \\
\text { gebyol. }\end{array}$ & $\begin{array}{l}\text { Sumber } \\
\text { penerangan bagi } \\
\text { aeisi rumah } \\
\text { (lambang matahari } \\
\text { jaman hindu). }\end{array}$ \\
\hline $\begin{array}{l}\text { Mega mendung } \\
\text { nistives }\end{array}$ & $\begin{array}{l}\text { Awan putih dan } \\
\text { awan hitam. }\end{array}$ & $\begin{array}{l}\text { Tepi blandar, } \\
\text { pintu, tebeng } \\
\text { jendela, tebeng } \\
\text { selkat. }\end{array}$ & $\begin{array}{l}\text { Sifat mendua: } \\
\text { laki-laki - } \\
\text { perempuan, hitam- } \\
\text { putih, sian-malam, } \\
\text { baik-buruk. }\end{array}$ \\
\hline $\begin{array}{l}\text { Banyu tetes } \\
\text { Bryesed }\end{array}$ & $\begin{array}{l}\text { Tetesan air yang } \\
\text { terkena sinar } \\
\text { matahari }\end{array}$ & $\begin{array}{l}\text { Beraamaan denan } \\
\text { patran, pada } \\
\text { ranglia }\end{array}$ & $\begin{array}{l}\text { Tiada kehidupan } \\
\text { tanpa air, } \\
\text { keindahan }\end{array}$ \\
\hline
\end{tabular}

\begin{tabular}{|c|c|c|c|}
\hline Nams & Wujud & Letak & Arti/maksud \\
\hline $\begin{array}{l}\text { Lung-lungan } \\
\text { fostogs? }\end{array}$ & $\begin{array}{l}\text { Tumbuhan menjalar } \\
\text { dibuat stilisasi } \\
\text { seperti tansman } \\
\text { surga, dengan daun, } \\
\text { bunga, dan } \\
\text { buah(merah, } \\
\text { hijsu, kuning, biru } \\
\text { ungu. }\end{array}$ & 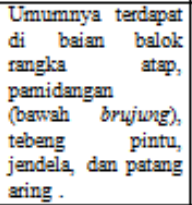 & $\begin{array}{l}\text { Estetiks } \\
\text { wingit. }\end{array}$ \\
\hline Saton & $\begin{array}{l}\text { Bentulk persegi } \\
\text { dengan hissan dsun } \\
\text { dan bunga, wama } \\
\text { hijsu, merah,aston } \\
\text { emas. }\end{array}$ & $\begin{array}{lr}\text { Ragam hias } & \text { terletak } \\
\text { di balok } & \text { angka } \\
\text { atap, } & \text { tiang } \\
\text { bangunan } & \text { atas } \\
\text { bawah, } & \text { tebeng } \\
\text { pintu. } & \end{array}$ & Keindahan. \\
\hline Wajikan & $\begin{array}{l}\text { Berbentuk belah } \\
\text { ketupat. Berisi daun } \\
\text { atsu bunga. Wama } \\
\text { kontras. }\end{array}$ & $\begin{array}{l}\text { Ragam hias terletak: } \\
\text { di tengah tiang atan } \\
\text { pada persilangan } \\
\text { balok pagar } \\
\text { bangunan. }\end{array}$ & $\begin{array}{l}\text { Lung-lungan di } \\
\text { samping sebagai } \\
\text { estetika juga } \\
\text { wingit. }\end{array}$ \\
\hline Nanasan & $\begin{array}{l}\text { Mirip nanas, omah } \\
\text { tawon, atan prit } \\
\text { gantil. Wama sesuai } \\
\text { dengan bangunan. }\end{array}$ & & $\begin{array}{l}\text { Keindahan dan } \\
\text { usaha keras } \\
\text { mendapatkan } \\
\text { kebahagiaen. }\end{array}$ \\
\hline $\begin{array}{l}\text { Tlacspan } \\
\text { AAAAA }\end{array}$ & $\begin{array}{l}\text { Deretan segitiga } \\
\text { sama tingi. Polos } \\
\text { atan berisi lung- } \\
\text { lungan. Wama emas } \\
\text { dengan dasar hijan } \\
\text { atsu merah tus. }\end{array}$ & $\begin{array}{l}\text { Pangkal dan ujung } \\
\text { balok kerangka } \\
\text { bangunan. }\end{array}$ & $\begin{array}{l}\text { Sinar matahari atsu } \\
\text { sorotan berarti } \\
\text { kacerahan dan } \\
\text { keagungan. }\end{array}$ \\
\hline Kabenan & $\begin{array}{l}\text { Mirip bush keben } \\
\text { meruncing seperti } \\
\text { mahkota. }\end{array}$ & $\begin{array}{l}\text { Blandar tumpang } \\
\text { ujung bawah salka } \\
\text { benthung lambang } \\
\text { gantung. }\end{array}$ & $\begin{array}{l}\text { Keindahan dan } \\
\text { proses dari yang } \\
\text { tidak sempuma } \\
\text { menuju sempuma. }\end{array}$ \\
\hline 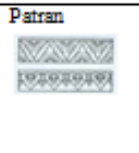 & $\begin{array}{l}\text { Dari kata patra } \\
\text { berarti daun. Bentuk } \\
\text { daun berderet }\end{array}$ & $\begin{array}{l}\text { Tepian atsu hiasan } \\
\text { pada bidan datar } \\
\text { kacil dan } \\
\text { memanjang di } \\
\text { baian balok rangka } \\
\text { bangunan. }\end{array}$ & $\begin{array}{l}\text { Keindihan dan } \\
\text { kesempumaen. }\end{array}$ \\
\hline $\begin{array}{l}\text { Padma } \\
\square \text { gegs }\end{array}$ & $\begin{array}{l}\text { Bunga teratai } \\
\text { bewama merah }\end{array}$ & $\begin{array}{l}\text { Terletak diatas } \\
\text { tiang (umpak). }\end{array}$ & $\begin{array}{l}\text { Estetika dan } \\
\text { kesucian (padma), } \\
\text { kolkoh, kuat }\end{array}$ \\
\hline
\end{tabular}

(Sumber: Cahyandari, 2012) 
Ragam hias alam menekankan peran semesta dan Tuhan. Kosmologi dualisme (siang malam, lakilaki-perempuan), orientasi, dan topografi yang di transformasikan dalam simbol yang berbentuk air, awan, sinar, dan matahari. Ragam hias agama membentuk hubungan antara hamba dengan Tuhan melalui simbol-simbol yang bernuansa keagungan dengan makna perlindungan. Letaknya menyesuaikan dengan fungsi bangunan.

Tabel 2. Ragam Hias Kepercayaan: Arti dan Penempatan

\begin{tabular}{|c|c|c|c|}
\hline Nama & Wujud & Letak & Arti/ maksud \\
\hline Mustaka & Kepala & $\begin{array}{l}\text { Di atap tajug, } \\
\text { untuk masjid } \\
\text { atau makam }\end{array}$ & $\begin{array}{lr}\text { Mahkota } & \text { atau } \\
\text { topong } & \text { wayang } \\
\text { tokoh raja } & \end{array}$ \\
\hline Sorotan & $\begin{array}{l}\text { Semacam } \\
\text { tombak }\end{array}$ & Di tiang saka & Tombak indrajit \\
\hline Mirong & $\begin{array}{l}\text { Sikap malu } \\
\text { atau susah } \\
\text { sekali } \\
\text { meninggalkan } \\
\text { tempat itu }\end{array}$ & $\begin{array}{l}\text { Di tiang } \\
\text { bangunan }\end{array}$ & $\begin{array}{l}\text { Kepercayaan. } \\
\text { Perwujudan } \\
\text { Kepercayaan } \\
\text { Kanjeng Ratu Kidul }\end{array}$ \\
\hline $\begin{array}{l}\text { Semacam } \\
\text { Kaligrafi }\end{array}$ & $\begin{array}{l}\text { Huruf arab, } \\
\text { distilisasi, di } \\
\text { rangkum, atau } \\
\text { kata Jawa }\end{array}$ & $\begin{array}{l}\text { Rangka } \\
\text { dadapeksi, } \\
\text { patang aring, } \\
\text { tebeng pintu, } \\
\text { tiang }\end{array}$ & $\begin{array}{l}\text { Nabi Muhammad } \\
\text { S.A.W., } \\
\text { Tuhan Yang Maha } \\
\text { Esa, mohon berkat. }\end{array}$ \\
\hline
\end{tabular}

(Sumber: Cahyandari, 2012 )

\section{Tipologi Arsitektur Tradisional Jawa}

Arsitektur Jawa memiliki peran penting sebagai penanda dalam menunjukkan kekuatan, status, dan privasi sehubungan dengan keyakinan kosmologis. Kosmologis sendiri memiliki makna dikotomi, misalnya pria dan wanita, sakral dan profan, publik dan privat, dan depan dan belakang (Ronald, 2005).

Tipologi Arsitektur Jawa dapat diklasifikasikan berdasarkan karakter atap dan pembagian ruang. Bentuk bangunan sendiri dapat dibagi menjadi beberapa tingkatan, mulai dari tingkatan yang paling tinggi yaitu tajuk (masjid), joglo (golongan ningrat), limasan (golongan menengah), kampung (rakyat biasa), dan panggang pe (raktyat biasa) (Cahyandari, 2012 ).

\section{Tata Ruang Masjid}

Masjid merupakan bangunan ibadah, yang berasal dari kata sajada atau sujud, yang berarti patuh, tunduk dan taat. Sujud dalam syariat adalah aktivitas berlutut meletakkan dahi, kedua telapak tangan dan kedua lutut di atas tanah/tempat sujud (Quradhawi, 2000).

Masjid memiliki pengertian yang lebih luas, tidak hanya sebatas tempat ibadah, namun untuk aktivitas sosial budaya masyarakat muslim, seperti ijab qabul, peng-Islaman, kajian keagamaan dan kegiatan lain yang bersifat pelestarian budaya, seperti yang terjadi di masjid-masjid kerajaan Islam di Jawa.
Sesuai Undang-Undang Nomor 26 Tahun 2007 tentang tata ruang dapat diambil satu pengertian bahwa tata ruang masjid adalah wujud struktur dari daerah masjid yang merupakan wadah manusia dalam melakukan kegiatan di masjid yang secara hierarki memiliki hubungan yang fungsional. Bahkan menurut Syamsiyah, et al. (2019) tata ruang masjid (ruang dalam dan ruang luar) berpengaruh terhadap terbentuknya pola spasial yang mengarah kepada keberlanjutan kenyamanan audial sebuah masjid.

\section{METODE PENELITIAN}

Metode yang digunakan dalam penelitian ini adalah metode kualitatif, baik untuk pendataan maupun proses analisis. Pemilihan metode kualitatif sebab peneliti ingin mengeksplor fenomena bentuk arsitektural masjid, yang tidak dapat dikuantitatifkan, sehingga hasil penelitian bersifat diskriptif (Sugiyono, 2012).

Penelitian ini menganalisis bagaimana keadaan peninggalan arsitektur Islam (dalam hal ini berupa masjid) di lingkungan masyarakat yang kental dengan kebudaayaan Jawa. Objek penelitian adalah dua masjid besar di lingkungan keraton, yaitu Masjid Agung Surakarta dan Masjid Gedhe Yogyakarta. Dimana observasi dilakukan di dalam masjid dan di sekitar lingkungan masjid. Pada penelitian ini objek sebagai sumber data dipilih secara purposive. Variabel penelitian ini lebih menitik beratkan pada gaya arsitektural masjid yang meliputi: sejarah ornamenasi, dan material yang dipakai. Variable lain yaitu yang berkaitan dengan tata ruang masjid: jenis ruang dan kegiatan di dalamnya. Pada penelitian kualitatif ini, data dikumpulkan dalam berbagai sumber, setting, dan teknik. Data diperoleh dari dua kategori sumber yaitu sumber primer observasi lapangan dan sumber sekunder dari referensi. Setting objek penelitian saat pengambilan data adalah sealamiah mungkin, apa adanya. Teknik pendataan terbanyak dengan pengamatan (observasi), kemudian dokumentasi dan wawancara sebagai data penguat saja saat dibutuhkan. Data dan analisis menggunakan metode deskriptif yang menggambarkan keadaan atau peristiwa tertentu berdasar fakta-fakta yang terlihat atau sebagaimana mestinya yang kemudian disertai dengan usaha untuk membuat kesimpulan umum berdasarkan fakta-fakta historis tersebut.

\section{HASIL DAN PEMBAHASAN}

\section{Perbandingan ornamen Masjid Agung Surakarta dan Masjid Gedhe Yogyakarta}

Gaya arsitektur tidak pernah lepas dari budaya, cara kehidupan dan keadaan geografis dari suatu daerah. Secara langsung maupun tidak langsung 
faktor-faktor tersebut mempengaruhi pola pikir masyarakakat dalam membangun suatu bentuk arsitektur di dua objek penelitian ini. Lebih jauh latar belakang sejarah berdirinya dua masjid keraton ini harus dipahami terlebih dahulu, agar dapat mengidentifikasi gaya arsitekturalnya.

Gaya arsitektur kedua masjid memiliki kesamaan dalam bentuk atap, dimana atap adalah yang bagian bangunan masjid yang paling mudah untuk dikenali dan mendominasi bentuk bangunan masjid sevara keseluruhan (Kartono, 2005). Atap masjid terdiri atas atap utama bersusun tiga, yang disebelah kanan dan kirinya terdapat atap limasan, sebagai penutup ruang dibawahnya, yang berfungsi sebagai pawastren dan ruang penunjang lainnya. Terakhir adalah atap di bagian depan atap utama, yaitu atap serambi masjid berbentuk limasan. Di bagian depan (timur) atap limasan terdapat atap memanjang kearah timur, dan di bawahnya merupakan pintu masuk masjid (batas suci). Beberapa gambar terkait bentuk atap lihat gambar 5. Gaya arsitektur lain yang tampak adalah bentuk bangunan panggung. Bentuk panggung merupakan peninggalan dari arsitektur Hindu, yang sudah berkembang lebih dahulu di Jawa, sebelum Islam masuk. Bentuk panggung pada bangunan peribadatan Hindu, yaitu candi terbagi atas tiga bagian, bagian terendah untuk fungsi komunal, hierarki berikutnya untuk fungsi komunal dan personal, dimana ibadah yang bersifat individu dan bersama ada di dalamnya, sebagai tempat mempersiapkan diri untuk ibadah yang bersifat individu, dan terakhir adalah hierarki tertinggi merupakan tempat berlangsungnya ibadah yang bersifat individual.

Gaya arsitektural bangunan dapat diketahui juga dari aspek ornamenasinya. Terdapat persamaan dan perbedaan ornamen yang ditemukan di Masjid Agung Surakarta dan Masjid Gedhe Kauman Yogyakarta.

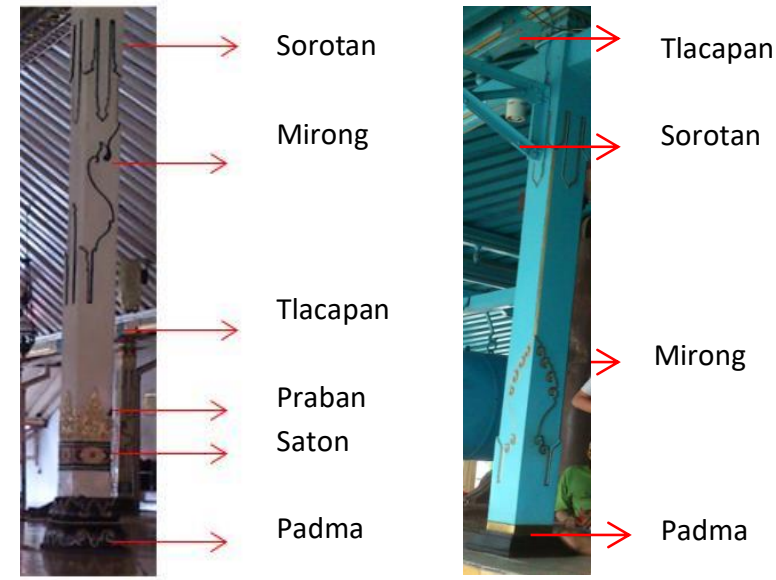

Gambar 1. Ornamen tiang di Masjid Kauman Yogyakarta (kiri) dan Masjid Gedhe Surakarta (kanan)
Berikut merupakan beberapa persamaan dan perbedaan ornamenasi bangunan:

\section{Ornamen pada tiang bangunan}

Tiang Masjid Gedhe Kauman Yogyakarta memiliki ornamen Jawa, seperti Padma, Saton, Praban, Mirong, Sorotan dan Tlacapan. Sedangkan pada Masjid Agung Surakarta hanya terdapat beberapa motif saja yaitu Mirong, Sorotan dan Tlacapan. Terdapat hal menarik pada tiang serambi Masjid Agung Surakarta bagian luar, yaitu ornamen tiang bangunan Yunani, yaitu ornamen langgam doric (Tim, 2014).
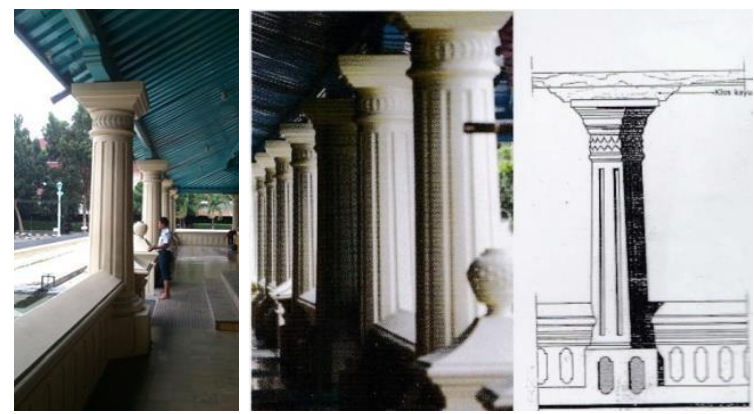

Gambar 2. Ornamen tiang langgam doric di Masjid Gedhe Surakarta

\section{Ornamen pada bagian langit-langit}

Ruang dalam masjid Gedhe Kauman Yogyakarta bagian langit-langit bukan hanya terdiri dari blandar dan usuk saja, tetapi terdapat tumpangsari, yang memiliki berbagai macam ornamen Jawa. Tumpangsari bermotif banyu tetes, tlacapan, lunglungan dan disudut pertemuan blandar terdapat nanas an. Masjid Gedhe Surakarta, dengan langitlangit atap tajug bermotif hias putri mirong dan bentuk saton. Ornamen Jawa pada tumpangsari menempel juga pada langit-langit serambi masjid.

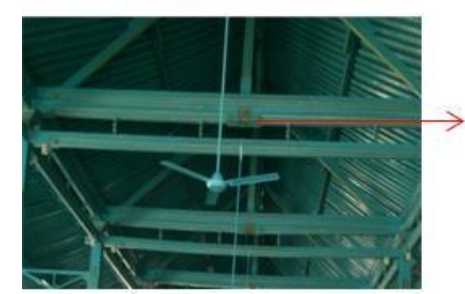

Seperti saton motif Bunga

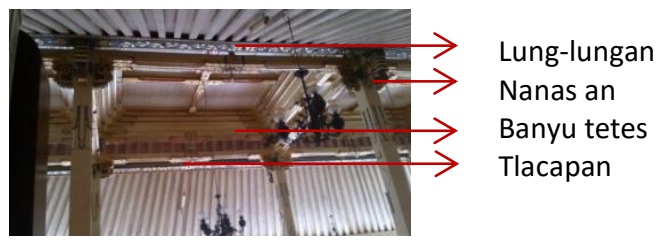

Gambar 2. Ornamen langit-langit di Masjid Kauman Yogyakarta (bawah) dan Masjid Gedhe Surakarta (atas) 


\section{Ornamen Pintu dan Jendela}

Pintu dan jendela dari kedua masjid memiliki kesamaan bentuk ornamen, yaitu berbentuk kaligrafi dan berbentuk flora seperti wajik. Sedangkan jendela pada kedua masjid pun sama, tidak berornamen, jendela dengan jeruji dan daun jendela kayu.
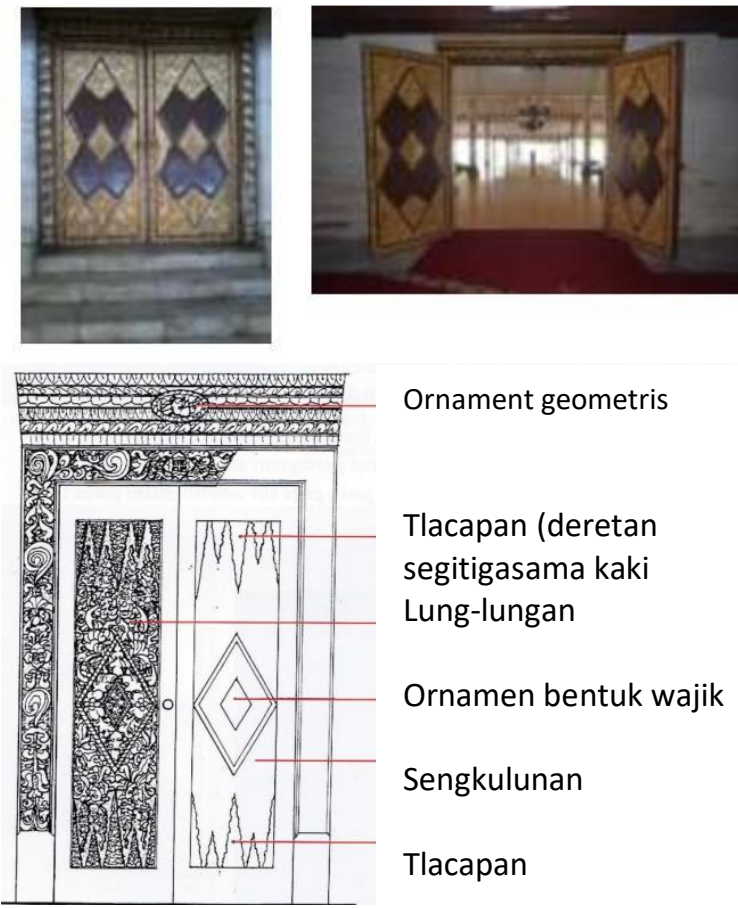

Ornament geometris

Tlacapan (deretan segitigasama kaki Lung-lungan

Ornamen bentuk wajik

Sengkulunan

Tlacapan

Gambar 3. Ornamen wajik pada pintu Masjid Kauman Yogyakarta (atas) dan Masjid Gedhe Surakarta (bawah)
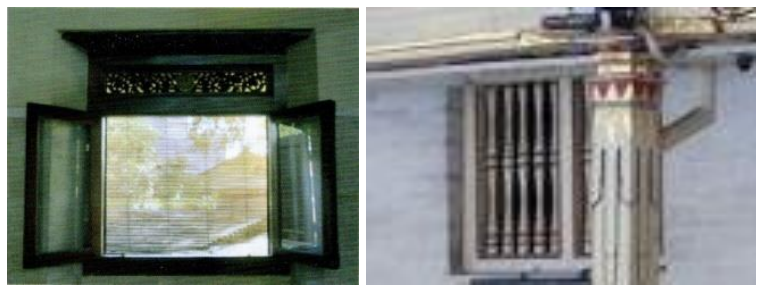

Gambar 4. Jendela kaca Masjid Gedhe Surakarta (kiri) dan jendela jeruji kayu Masjid Kauman Yogyakarta (kanan)

\section{Ornamen Pada Atap}

Atap kedua masjid memiliki bentuk sama, yaitu atap tajuk tiga tingkat. Bentuk ini merupakan pengaruh dari seni arsitektur era Majapahit, seperti pada bangunan candi. Adapun perbedaan pada mahkota atap atau mustaka. Atap Masjid Kauman Yogyakarta menggunakan bentuk mustaka daun kluwih dan gada. Sementara itu masjid Gedhe Surakarta menggunakan mustaka bentuk kubah yang tertancap oleh benda seperti paku yang besar di puncak atap.

Bagian atap pada pintu masuk halaman masjid terdapat perbedaan signifikan, yaitu bentuk setengah lingkaran di Masjid Kauman Yogyakarta dan bentuk segitiga di Masjid Gedhe Surakarta. Pada atap di bagian pintu masuk tidak terdapat ornamen untuk
Masjid Gedhe Surakarta, tetapi pada Masjid Kauman Yogyakarta terdapat ornamen lambang keraton kasultanan Yogyakarta dan jam besar.
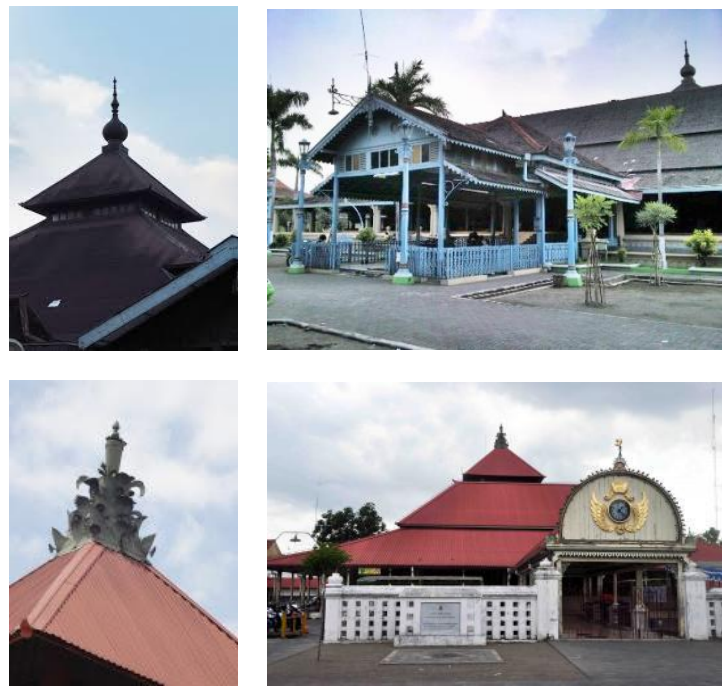

Gambar 5. Mustaka di atap masjid dan pintu masuk Masjid Gedhe Surakarta (atas) dan Masjid Kauman Yogyakarta (bawah)

\section{Perbandingan Material Masjid Agung Surakarta dan} Masjid Gedhe Yogyakarta

Material kedua bangunan masjid menggunakan kayu sebagai struktur utama dan batu bata sebagai pengisi dinding bangunan, pintu dan jendela juga masih menggunakan material kayu. Penyelesaian material dinding Masjid Gedhe Surakarta sudah mengalami perubahan, dinding dilapisi keramik. Masjid Kauman Yogyakarta, menggunakan batu paras putih berbahan dasar batu pasir berspesi ukuran 30 $\mathrm{cm} \times 5 \mathrm{~cm}$.

Masjid Kauman Yogyakarta lebih terjaga keaslian materialnya, dibandingkan Masjid Gedhe Surakarta, kecuali material lantai, yang berubah dari material batu kali berwarna hitam menjadi lantai marmer Itali hingga sekarang, yang diganti tahun 1936.

\section{Tata Ruang Masjid}

Kedua masjid kerajaan memiliki pola tata ruang yang hampir sama yaitu terdiri dari ruang utama untuk sholat indoor, keputren/pawastren, serambi masjid selasar masjid dan tempat wudlu dan kamar mandi. Perbedaan ada pada penggunaan ruang keputren/ pawastren. Pawastren di Masjid Kauman Yogyakarta difungsikan untuk sholat jamaah putri hanya pada hari Jumat saja, sedangkan hari lain jamaah putri sholat lima waktu di dalam ruang utama, terpisah partisi/ hijab dengan jamaah putra. Tempat sholat jamaah putri di sisi tenggara ruang utama. Sedangkan pawastren di Masjid Gedhe Surakarta digunakan setiap harinya sesuai fungsi yaitu tempat sholat jamaah putri. 

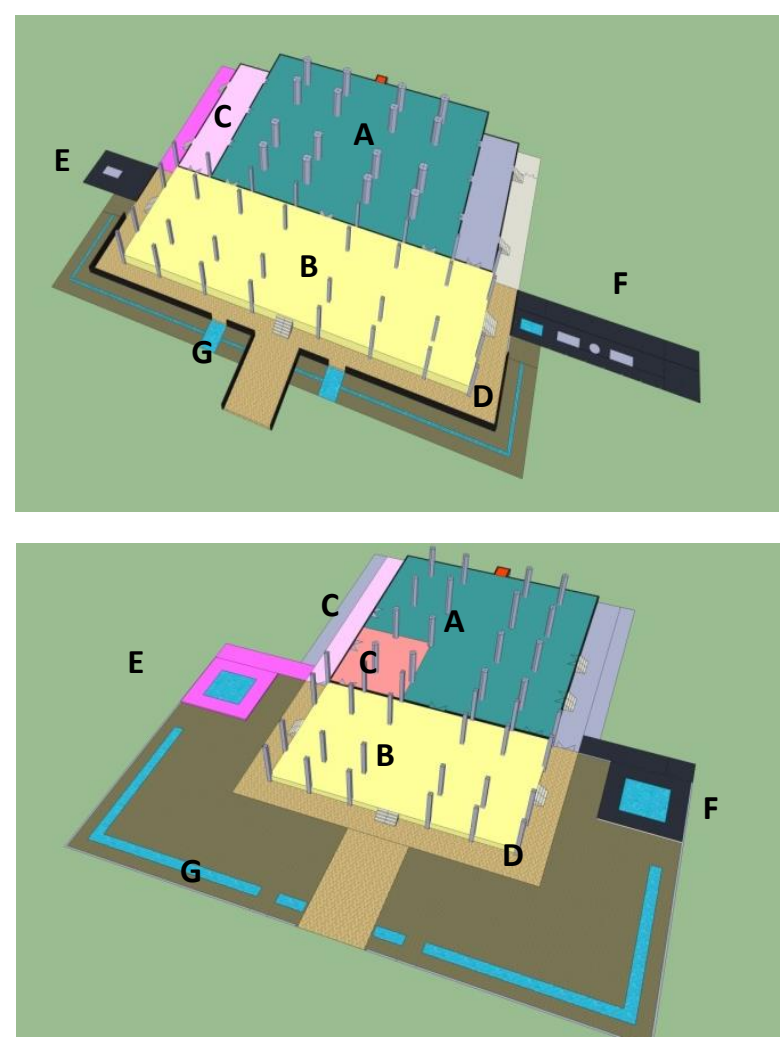

Keterangan gambar:

$A=$ tempat sholat utama untuk putra

$B=$ serambi masjid

$C=$ tempat sholat untuk putri (pawastren), khusus Masjid

Kauman Yogyakarta terdapat dua tempat sholat putri

$\mathrm{D}=$ teras masjid

$E$ = tempat wudhu putri

$\mathrm{F}=$ tempat wudhu putra

$\mathrm{G}=$ kolam

Gambar 6. Masjid Gedhe Surakarta (atas) dan Masjid Kauman Yogyakarta (bawah)

Secara umum Masjid Kauman Yogyakarta dan Masjid Gedhe Surakarta memiliki gaya arsitektur bangunan dan ornamentasi serta tata ruang yang sama. Namun apabila dilihat kembali lebih detail terdapat perbedaan, yang tentunya disebabkan ide atau gagasan dan pola pikir penguasa dan masyarakat pada saat itu. Masjid Agung atau Masjid Gedhe Surakarta dibangun saat Paku Buwono ke-3 tahun 1749. Sejarah telah menjelaskan bahwa masa PB III banyak memiliki kedekatan dengan Negara-negara di Eropa, sehingga ornamen dan bentuk arsitektur dipengaruhi gaya arsitektur Eropa, seperti pada tiang serambi/teras. Begitupun raja-raja setelahnya turut memberikan pengaruh bentuk arsitektur, seperti menara dan pintu masuk pekarangan masjid yang memiliki gaya Timur Tengah, Persia dan India. Berbeda sekali dengan Masjid Kauman Yogyakarta yang dibangun pada tahun 1773, dimana gaya arsitektur tradisional Jawa lebih dipertahankan keasliannya. Hal ini sebagai bukti sejarah bahwa berdirinya Kasultanan Yogyakarta berasal dari adanya perpecahan yang membagi kerajaan Islam Mataram menjadi dua, sebagai hasil perjanjian Giyanti tahun 1755, yaitu Kasultanan Yogyakarta dengan gelar Hamengkubuwono I dan Kasunanan Surakarta dengan gelar PakuBuwono III. Adanya dua kerajaan berdampak pada adanya perbedaan keputusan raja termasuk dalam menentukan pola rancangan masjid.

\section{KESIMPULAN}

Baik masjid Agung Surakarta dan Masjid Gedhe Kauman Yogyakarta merupakan masjid bercorak Jawa dibuktikan dengan penggunaan kaidah- kaidah Jawa seperti struktur kayu, atap tajuk, pola ruang dan penggunaan ornamen-ornamen Jawa. Namun pada Masjid Gedhe Surakarta terjadi perubahan, yaitu pada gaya arsitektur dan penggunaan material. Gaya arsitektur terpengaruh Eropa, Timur Tengah (Persia) dan India. Material lama/asli dilapisi oleh material baru terutama dinding batu bata menjadi dilapisi keramik.

Berkaca dari kasus dua masjid ini memberikan pelajaran bahwa siapa yang memiliki kekuasaan atau kepentingan penguasa akan berpengaruh terhadap keberadaan masjid, baik pola tata ruang, ornamen maupun bentuk arsitektur. Hal ini disebabkan penguasa atau raja bertindak sebagai penguasa atau pemerintah sekaligus juga sebagai pemimpin agama, dengan istilah Panatagama Khalifatullah .

\section{DAFTAR PUSTAKA}

Cahyandari, G. O. (2012 ). Tata Ruang dan Elemen Arsitektur pada Rumah Jawa di Yogyakarta. Jurnal Arsitektur Komposisi, Volume 10 Nomor 2, 105-111.

Kartono, J. L. (2005 Vol.3 No.2). Konsep ruang tradisional Jawa dalam konteks budaya. Dimensi Interior, 133.

Quradhawi, A. Y. (2000). Tuntunan Membangun Masjid. jakarta: Gema Insani Press.

Ronald, A. (2005). Nilai-nilai Arsitektur Rumah Tradisional Jawa. Yogyakarta: Gadjah Mada University Press.

Sugiyono. (2012). Metode Penelitian Kuantitatif, Kualitatif dan $R \& D$. Bandung: Alfabeta.

Surakarta, T. P. (2014). Sejarah Masjid Agung Surakarta ISBN87-4. 978-602-7709-. Yogyakarta: Absolute Media.

Syamsiyah, N (Maret 2019). Soundscape Kawasan: Evaluasi Ruang Berkelanjutan. ARCADE (Sinta 5) Volume 3 tahun 1.

Vitruvius, M. H. (1914). The Ten Books on Architecture. London: Harvard University Press. 